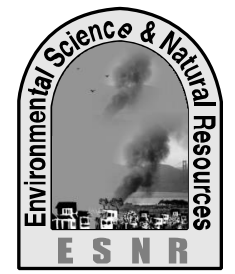

\title{
Impact of Land Tenure System on Socio-Economic Characteristics in Selected Areas of Mymensingh
}

\author{
Z. Haque and T. Jinan*
}

Department of Agricultural Finance

Bangladesh Agricultural University, Mymensingh-2202, Bangladesh

*Corresponding author: tanjima_jinan@yahoo.com

\begin{abstract}
The present study aims at investigating into the existing land tenure system of Dorirampur, Jhairpar and Goisa para at Traishal Upazila of Mymensingh District. Keeping in view the objectives 70 samples were randomly selected. Survey method was followed to collect required data. Sampled farmers belonged to six tenurial groups. Out of 70 respondents $34,22,16,7,10$ and 11 percent of total were owner operators, part operators, part tenants, part operator-cum-part tenants, tenants and absentee landowners respectively during the study year. In the study, out of 70 respondents 67 percent were owner operator, 33 percent of them were tenant operators. The selected farmers in the study area practiced three types of share cropping system: i) fifty-fifty share cropping, ii) forty-sixty share cropping and iii) fixed amount of paddy payment. The average annual income were found to be Tk. 97096, 128267, 5215, 76340, 35871 and 113563 respectively for owner operator, part operators, part tenants, part operator-cum-part tenants, tenants and absentee landowner. Analysis of annual income reveals a positive relationship between tenure category and that of annual income during the study area.
\end{abstract}

Keywords: Land Tenure, Socio-Economic.

\section{Introduction}

Tenancy is an important historical feature of agriculture in all countries of the world specially many developing ones. More than one-sixth of the total cultivated lands in Bangladesh are operated under different tenurial arrangements (Taslim and Ahmed, 1992). The agrarian structure of Bangladesh is characterized by the prevalence of small and fragmented holdings, dominance of traditional method of cultivation and unjustifiable land tenure system. Most of the cultivable land managed under various tenancy arrangements suffers from serious bottlenecks particularly the disproportionate output share given to the tenants compared to their materials as well as nonmaterial efforts rendered in the whole process of production activities.

\section{Importance of agriculture in the economy of Bangladesh}

Agriculture is still the leading sector of Bangladesh economy and as such growth and stability of Bangladesh economy depend largely on balanced growth of agriculture (crops, livestock, fisheries and related others). Agriculture contributed 21.11 percent to the countryôs total GDP. About 52 percent of the total labor forces are still employed directly or indirectly in agriculture (MoF, 2007). This sector not only employs majority of the national active labor force but also supplies food for human beings as well as other sub-sector and raw materials for industrial production; sustaining the rural economy and tries to balance the environmental eco-system to a greater extent.

\section{Role of land tenure arrangements in Bangladesh}

Agriculture is the heart as well as centre to the Economy of Bangladesh but perhaps more important to be the basic sector for overall future economy growth. Bangladesh has continuously been facing the problem of inadequate production and development in various sub-sectors of agriculture attributing to a good number of factors of which land tenure system and vulnerable financial aspects are quite worth mentioning.

The system of land tenure in a country determines the legal and customary relationship between the land, the cultivator and the other parties having interest in such land. It is the body of laws and customs which determines the relationship between land, people and the government in respect of ownership, control and use of land. It determines the size of the unit of ownership and cultivation and thus directly or indirectly the techniques of farming through a socioeconomic level of incentives or disincentives. Land tenure affects the volume of agricultural production in many ways as well as determines the distribution among the parties involved and consequently the incentives imparts to the actual worker, engaged in agricultural operation. 
Major uncertainties as to what can be expected are short-term leases with no assurance of renewal and from possible loss of land ownership because of heavy fixed mortgaged commitments, price and yield uncertainties etc. Under these conditions the farmerôs planning horizon becomes less than the optimum planning period. As a result, he is motivated to use his labor and capital for short run productive efforts for consumption purposes and thus his productivity is reduced.

A good and favorable system of land tenurial arrangements, on the other hand, exerts a helpful economic implication to the economy. This system of leasing arrangements would help many farmers to command over a large acreage of land resources than would be the case if they would have own land. A farmer having less acreage of land at his disposal, with adequate knowledge, labor and other capital would be able to farm efficiently and profitably at given context of renting in/mortgaging in land from others.

\section{Share cropping}

The term ñshare cropperò has come from the concept ñshare rentò. Under this system a farmer has to pay a fixed amount of rent either in cash or in kind to the landowner. Fixed cash rent is known as ñstanding rentò and the renter is termed as ñcash tenantò. Payment is kind is called ñshare rentò and the renter is termed as ñshare tenantò. The farmers who operate on share cropping arrangement are locally called ñBorgaderò or ñAdhiarò. The present study is conducted on the basis of those sharecroppers who cultivate definite piece of land for a crop year with their own working capital and family labor to share the total output after the harvest with the landowners on a 50:50 share basis.

\section{Tenancy of share cropping}

Agricultural development in an agrarian economy largely depends on the existing nature of man-land relationship. Crop sharing is one of the earliest forms of organizing production in agriculture. It is still a matter of considerable importance in present agriculture in many countries of the world. According to Bishop and Toussaint, both landlord and tenant are utilizing inputs belonging to respective parties (Bishop and Toussaint, 1958). Each party may consider the inputs contributed another to have a zero price. In this case, there will be a tendency to use the other personôs input up to the point where the value of the marginal product is zero. For example, the tenantôs labor has no price to the land lord. The land lord tends to push the use of tenantô labor, in so far as he is able to reach the point where additional labor brings no returns. That is, landlord would like to see enough labor used so that the value of the marginal product of labor would be zero. The tenant on the other hand, considers the price of land to be zero. He has incentive to use additional land as long as the value of the marginal product of the land greater than zero. But the land has a cost to the land lord. For this reason a conflict of interest may develop between land owner and the tenant. The crucial problem of growth in agriculture in Bangladesh is how to increase the output per unit of input. One way of approaching this problem of improving agricultural production efficiency is to examine whether the present ownership pattern as well as resources use is efficient or inefficient. Due to natural hazards, share croppers do not usually take the risk of extra investment in their farm business. The sharecropper is quite reluctant to seek any technological improvement in organizing his farm business. Resource use and production under different tenure groups of farms in the less developed countries has been one of the most widely discussed and controversial issues in development literature. In recent years more theoretical and empirical contributions have been made (Mandal, 1979) which added diverse dimensions to this issue, although basic controversy still seems to be unresolved.

\section{Methodology}

Selection of the study area is an important step for the study because it indicates a premise from where required data would be collected in accordance with the objectives set for the study. To achieve the objective of the present study, Rampur and Dhanikhola unions under Trishalupazila of Mymensingh district were selected purposively as study area.

\section{Preliminary works}

Before starting the actual data collection, it was felt desired to contact the farmers to create a friendly and congenial atmosphere for successful continuation of the survey and rousing in them so that they would respond actively in it. Prior acquaintance with the people concerned was made to gain their support and confidence, so that they could furnish actual information without fear and confusion to be beneficial for achieving the set objectives.

\section{Preparation of the schedule}

A draft schedule was first prepared having advice of the supervisor and five samples were pre-tested in the study villages before going for final data collection. The survey schedule was finalized after making necessary correction, modification and adjustments based on the pretest. 


\section{Selection of sample and sampling technique}

Sample selection is an important part of survey work. It is generally not possible to make census covering all the borrowers and it is not worthwhile to include too many borrowers in a survey because of obvious reasons. Farmers were randomly selected from whom required data were sought during intensive field visits. After final selection of the farmers, the researcher himself moved around the study area to collect data administering prepared survey schedules.

\section{Period of survey}

For present study, data were collected during the period from March to April, 2008 and multi visits were made for collecting necessary information during this period.

\section{Collection of data}

Data collection is an important step and results of any study depend on the accuracy and reliability of data. The accuracy and reliability of data mostly depend on the method of collection. The study was mainly based on a set of field level primary data collected from the selected members by using previously prepared interview schedule. Field level primary data were collected from the selected respondents through direct interview conducted by the researcher himself. Usually the respondents at grass root level do not keep written records of their different activities, so the researcher had to depend on bare memory of the respondents. During interview, the researcher asked questions systematically and explained whenever necessary. After completion of each interview, the schedule was checked and verified to be sure that answer had been properly recorded. In order to minimize time and for easy understanding, data were collected in local units. Local units were subsequently converted into standard units.

\section{Results}

Land tenure system in the study area

Land tenure means exercising right to the use of land. People hold varying kinds of right in the use of land and are said to belong to different tenure classes. Recent statistics on land tenure in Bangladesh suffers from two major deficiencies: i) the various census and surveys providing information have used quite dissimilar classifications and ii) the various dissimilar classifications together are inadequate to abstract all the tenure relationships prevailing in rural Bangladesh. Most of the studies in the past dealt with three elements i.e., owned land, rented in land and rented out land in the classification of land tenure categories (Pakistan 1962, Jabbar 1977). Using these three elements, some of the above studies classified land tenure into three categories, namely-a)owner operatorthose cultivating own land, b) owner-cum-tenant-those owning some land and renting in additional land from others and c) tenants-those renting in all the land cultivated. However, Jabbar (1977), Hasan (1983) and Sikder (1985) have shown two additional land tenure categories by using the same elements i.e., a) absentee or non-cultivator owners-those owning land but not cultivating the same by own and b) part operator-those cultivating part of owned land and rent out the rest. The shortcomings of these two classifications were taken into account in another study made by Jabbar (1977). In this study he brought two additional elements into consideration and identified 17 different tenure categories. The two additional elements were mortgaged in and mortgaged out land.

In present study, the researcher could identify six categories of land tenurial arrangements in practice in the study area which are as below:

a) Owner operator: Households who cultivate all land areas they own.

b) Part operator: Households who cultivate part of their own land area and rent out and/or mortgage out part of the land to others.

c) Part tenant: Households who cultivate their entire owned area and rent in and/or mortgage in additional land from others.

d) Part operator-cum-part tenant: Households who cultivate part of own land, rent out and/or mortgage out part of their own land and at the same time rent in and/or mortgage in land from others.

e) Tenant: Households having no cultivable land of their own at all but rent in and/or mortgage in land from others for cultivation.

f) Absentee land owner: Households who own land but donâ cultivate land at all by themselves. All of their land areas are rented out and/or mortgage out. They usually are engaged in other professions.

Tenurial arrangements and input-output sharing in the study area

Fifty-fifty share cropping is the most common sharing arrangement in the study area. With this arrangement, land owner provides land, some variable inputs and the tenant provides variable inputs of labor, seeds, management etc. In some places, mostly in irrigated areas, landlord provides half of the irrigation cost in the case of motor pump. But for engine pump/deep tube-well, the landlord provides the machine/deep tube-well charge only, and the tenant gives all the fuel 
and management cost for irrigation. Sometimes, the landlord provider half of seeds and insecticides as variable input and the straw is divided into fifty-fifty basis, but if the land owner does not pay the seed and insecticide cost, then the tenant gets all of the straw and the rice is divided into fifty-fifty basis. The landlord provides half of fertilizer cost in share cropping system.

\section{Distribution of sample farmers under investigation}

Sampled farmers belonged to major two groups of tenurial arrangements. These are as follows:

i) Owner operator- part operator and absentee land owner were considered as owner operator/land owner group in the sense that they cultivate their land or part/fully rented out/mortgaged out their land.

ii) Tenant operator-part tenant, part operator-cumpart tenant were considered as tenant operator groups in the sense that they rented in/mortgaged in the land.

Table 1. Distribution of the sample farmers according to major tenure categories

\begin{tabular}{l|c|c}
\hline \multicolumn{1}{c|}{ Tenure category } & Number & Percent \\
\hline Owner Operator/land Owner & 47 & 67 \\
Tenant operator & 23 & 33 \\
Total & 70 & 100 \\
\hline Source: Field Survey, 2008 &
\end{tabular}

Table 1 indicates that out of 70 respondents 67 percent were owner operator/land owner, 33 percent of them were tenant operators in the study area.

\section{Rental arrangements of the tenant operators}

Generally two types of rental arrangements were practiced in the study area. One was share cropping and another was cash rental arrangements. Table 2 indicates that out of 23 tenant operators 35 percent were share cropping practiced and 65 percent were cash rental practiced in the study area.

Table2. Distribution of tenant operators according to rental arrangements

\begin{tabular}{lc|c}
\hline \multicolumn{1}{c|}{ Type } & Number & Percent \\
\hline Share cropping & 8 & 35 \\
Cash-rent & 15 & 65 \\
Total & 23 & 100 \\
\hline
\end{tabular}

Source: Field Survey, 2008

\section{Share cropping in the study area}

The selected farmers in the study area practiced three types of share cropping system:

i) Fifty-fifty share cropping

ii) Forty-sixty share cropping

iii) Fixed amount of paddy payment

Table 3 shows that in case of fifty-fifty sharing the land owner provides 50 percent fertilizer, seed and insecticides and 100 percent deep tube-well charge while the tenant provides 100 percent fuel/electricity cost. Then the output paddy and straw are distributed 50:50 basis.

In case of forty-sixty sharing, the land owner provides 50 percent fertilizer, deep tube-well water charge and tenant provides 100percent fuel, seed and insecticides cost. Then the paddy is distributed 40:60 basis and the tenants get all of the straw.

Other types of sharing is fixed amount of paddy payment. It is a contractual arrangement. In this regulation the tenant must give 1 mounds of paddy per katha, whether the tenant can produce or not. 
Table 3. Input-output sharing according to share cropping tenancy

\begin{tabular}{|c|c|c|c|c|c|}
\hline \multirow{3}{*}{ Input } & \multicolumn{5}{|c|}{ Fifty-fifty share cropping } \\
\hline & \multicolumn{2}{|c|}{ Sharing (percent) } & \multirow[t]{2}{*}{ Output } & \multicolumn{2}{|l|}{ Sharing (percent) } \\
\hline & Land owner & Tenant & & Land owner & Tenant \\
\hline i) Fertilizer & 50 & 50 & i)Paddy & 50 & 50 \\
\hline \multicolumn{6}{|l|}{ ii) Irrigation } \\
\hline a) Deep tube-well charge & 100 & - & ii)Straw & 50 & 50 \\
\hline b) Fuel/Electricity cost & - & 100 & & & \\
\hline iii) Seeds & 50 & 50 & & & \\
\hline iv) Insecticides & 50 & 50 & & & \\
\hline \multicolumn{6}{|l|}{ Forty-sixty share cropping } \\
\hline i) Fertilizer & 50 & 50 & i)Paddy & 40 & 60 \\
\hline \multicolumn{6}{|l|}{ ii) Irrigation } \\
\hline c) Deep tube-well charge & 50 & 50 & ii)Straw & 40 & 60 \\
\hline d) Fuel/Electricity cost & - & 100 & & & \\
\hline iii) Seeds & - & 100 & & & \\
\hline iv) Insecticides & - & 100 & & & \\
\hline \multicolumn{6}{|c|}{ Fixed amount of paddy payment } \\
\hline i) Fertilizer & - & 100 & i)Paddy & 1 mounds/katha & Rest of \\
\hline ii) Irrigation & & & & & \\
\hline e) Deep tube-well charge & - & 100 & & & product \\
\hline f) Fuel/Electricity cost & - & 100 & & & \\
\hline iii) Seeds & - & 100 & ii)Straw & - & 100 \\
\hline iv) Insecticides & - & 100 & & & \\
\hline
\end{tabular}

Source: Field Survey, 2008

Socio-economic characteristics of the surveyed families

Socio-economic characteristics of the respondents may have an important bearing on the farm production. So it is rational to examine some of the important socioeconomic characteristics of the farmers and farmers households

Table 4. Age distribution of the family members of the respondents

\begin{tabular}{l|c|c|c|c|c|c|c|c}
\hline \multirow{2}{*}{ Tenure category } & \multicolumn{4}{c|}{ Male } & \multicolumn{4}{c}{ Female } \\
\cline { 2 - 8 } & $\begin{array}{c}\text { Below } \\
\text { 15years }\end{array}$ & $\begin{array}{c}15-57 \\
\text { years }\end{array}$ & $\begin{array}{c}\text { Above } \\
57 \text { years }\end{array}$ & $\begin{array}{c}\text { Sub- } \\
\text { total }\end{array}$ & $\begin{array}{c}\text { Below } \\
15 \text { years }\end{array}$ & $\begin{array}{c}15-57 \\
\text { years }\end{array}$ & $\begin{array}{c}\text { Above } \\
57 \text { years }\end{array}$ & $\begin{array}{c}\text { Sub- } \\
\text { total }\end{array}$ \\
\hline Owner operator & 0.71 & 1.96 & 0.25 & 2.91 & 0.54 & 1.58 & 0.17 & 2.29 \\
& $(17)$ & $(47)$ & $(6)$ & $(70)$ & $(13)$ & $(38)$ & $(4)$ & $(55)$ \\
Part operator & 0.4 & 2.6 & 0.27 & 3.27 & 0.47 & 1.73 & 0.2 & 2.4 \\
& $(6)$ & $(39)$ & $(4)$ & $(49)$ & $(7)$ & $(26)$ & $(3)$ & $(36)$ \\
Part tenant & 0.36 & 2.36 & 0.27 & 3.0 & 0.27 & 1.82 & 0.36 & 2.45 \\
& $(4)$ & $(26)$ & $(3)$ & $(33)$ & $(3)$ & $(20)$ & $(4)$ & $(27)$ \\
Part operator- & 0.8 & 2.0 & 0.2 & 3.0 & 0.6 & 1.4 & 0.2 & 2.2 \\
cum-part tenant & $(4)$ & $(10)$ & $(1)$ & $(15)$ & $(3)$ & $(7)$ & $(1)$ & $(11)$ \\
Tenant & 0.71 & 2.29 & 0.43 & 3.43 & 0.57 & 1.57 & 0.29 & 2.43 \\
& $(5)$ & $(16)$ & $(3)$ & $(24)$ & $(4)$ & $(11)$ & $(2)$ & $(17)$ \\
Absentee land & 0.5 & 2.25 & 0.25 & 3.00 & 0.50 & 1.38 & - & 1.88 \\
owner & $(4)$ & $(18)$ & $(2)$ & $(24)$ & $(4)$ & $(11)$ & $(15)$ \\
All categories & 0.57 & 2.23 & 0.27 & 3.07 & 0.49 & 1.61 & 0.20 & 2.30 \\
& $(40)$ & $(156)$ & $(19)$ & $(215)$ & $(34)$ & $(113)$ & $(14)$ & $(161)$ \\
\hline
\end{tabular}

Source: Field Survey, 2008; Figure in parentheses indicate the total number 
Age

Age of the respondents was classified into three categories such as below 15 years, 15-57 years and above 57 years. The $15-57$ years is considered as working group. It is clear from Table 4 that more family members within active age group and the female members were found engaged in some income generating activities.

\section{Education}

Education is the back bone of a nation. Education plays an important role in accelerating the pace of economic development as well as agricultural development. The illiteracy of the rural people is considered to be one of the main barriers towards modernization of agricultural production. To examine the extent of literacy level of the respondents, literacy level was classified into four categories. Those who can neither read nor write were considered as illiterate (Table 5). The Table 5 reveals that 34 percent of total respondents were illiterate having no formal education in the study villages. Another 32 percent were found within the level of primary education and only 1 and 13 percent of the respondents belonged to the level of SSC and above SSC respectively.

Table 5. Level of education of the respondents (percent)

\begin{tabular}{|c|c|c|c|c|c|}
\hline \multirow[t]{2}{*}{ Tenure category } & \multicolumn{5}{|c|}{ Level of Education } \\
\hline & Illiterate & Primary & S.S.C & Above S.S.C & Total \\
\hline \multirow[t]{2}{*}{ Owner operator } & 29 & 33 & 25 & 13 & 100 \\
\hline & (7) & (8) & (6) & (3) & (24) \\
\hline \multirow[t]{2}{*}{ Part operator } & 40 & 27 & 20 & 13 & 100 \\
\hline & (6) & (4) & (3) & (2) & (15) \\
\hline \multirow[t]{2}{*}{ Part tenant } & 46 & 36 & 18 & - & 100 \\
\hline & (5) & (4) & (2) & & (11) \\
\hline \multirow{2}{*}{$\begin{array}{l}\text { Part operator-cum-part } \\
\text { tenant }\end{array}$} & 40 & 40 & 20 & - & 100 \\
\hline & (2) & (2) & (1) & & (5) \\
\hline \multirow[t]{2}{*}{ Tenant } & 57 & 43 & - & - & 100 \\
\hline & (4) & (3) & & & (7) \\
\hline \multirow[t]{2}{*}{ Absentee land owner } & - & 12 & 38 & 50 & 100 \\
\hline & & (1) & (3) & (4) & (8) \\
\hline \multirow[t]{2}{*}{ All categories } & 34 & 32 & 21 & 13 & 100 \\
\hline & (24) & (22) & (15) & (9) & (70) \\
\hline
\end{tabular}

Source: Field Survey, 2008; Figures in parentheses indicates the total number

Family size

It appears from the Table 6 that overall family size of the respondents was 5.37 being a little bit greater than national average $(4.90 ; \mathrm{BBS}, 2006)$. It also shows that the average family size of 5.37 persons constituted
3.07 males and 2.30 females. The dependency ratio was the highest (3.00) in case of the absentee land owner followed by owner operator (2.98), part operator (2.43), part tenant (2.40), part operator-cum-part tenant (2.89) and tenant (2.28) during present study.

Table 6. Family size, the distribution of earning and dependent persons of the respondents

\begin{tabular}{l|c|c|c}
\hline Tenure category & Average family size & $\begin{array}{l}\text { Average earning } \\
\text { member }\end{array}$ & Dependency ratio \\
\hline Owner operator & 5.21 & 1.75 & 2.98 \\
Part operator & 5.67 & 2.33 & 2.43 \\
Part tenant & 5.45 & 2.27 & 2.40 \\
Part operator-cum-part tenant & 5.20 & 1.80 & 2.89 \\
Tenant & 5.86 & 2.57 & 2.28 \\
Absentee land owner & 4.88 & 1.63 & 3.00 \\
All categories & 5.37 & 2.03 & 2.65 \\
\hline
\end{tabular}

Source: Field Survey, 2008

Occupation of the farmers

Table 7 shows the occupation of the respondents. It appears from the table that more than 51 percent of the total sampled farmers had agriculture as their sole occupation taking all tenure categories together during the year. Taking the absentee land owners into account, business and service in different government as well as private offices were found important as main source of income and agriculture as subsidiary one to the respondents in the study villages. 
Table 7. Occupation of the respondents according to tenure category

\begin{tabular}{|c|c|c|c|c|c|c|c|c|c|c|}
\hline \multirow[t]{2}{*}{$\begin{array}{l}\text { Tenure } \\
\text { category }\end{array}$} & \multicolumn{2}{|c|}{ Only farming } & \multicolumn{2}{|c|}{$\begin{array}{l}\text { Farming major and } \\
\text { other minor } \\
\text { occupation }\end{array}$} & \multicolumn{2}{|c|}{$\begin{array}{l}\text { Farming minor } \\
\text { and other major } \\
\text { occupation }\end{array}$} & \multicolumn{2}{|c|}{$\begin{array}{l}\text { Occupation other } \\
\text { than farming }\end{array}$} & \multicolumn{2}{|c|}{ Total } \\
\hline & No & Percent & No & Percent & No & Percent & No & Percent & No & Percent \\
\hline $\begin{array}{l}\text { Owner } \\
\text { operator }\end{array}$ & 15 & 63 & 7 & 29 & 2 & 8 & - & - & 24 & 100 \\
\hline $\begin{array}{l}\text { Part } \\
\text { operator }\end{array}$ & 10 & 67 & 4 & 27 & 1 & 6 & - & - & 15 & 100 \\
\hline Part tenant & 6 & 55 & 4 & 36 & 1 & 9 & - & - & 11 & 100 \\
\hline $\begin{array}{l}\text { Part } \\
\text { operator- } \\
\text { cum-part } \\
\text { tenant }\end{array}$ & 3 & 60 & 2 & 40 & - & - & - & - & 5 & 100 \\
\hline Tenant & 2 & 29 & 1 & 14 & 4 & 57 & - & - & 7 & 100 \\
\hline $\begin{array}{l}\text { Absentee } \\
\text { land owner }\end{array}$ & - & - & - & - & 4 & 50 & 4 & 50 & 8 & 100 \\
\hline $\begin{array}{l}\text { All } \\
\text { categories }\end{array}$ & 36 & 51 & 18 & 26 & 11 & 16 & 5 & 7 & 70 & 100 \\
\hline
\end{tabular}

Source: Field Survey, 2008

\section{Distribution of land holding}

In the Table 8, on an average farm size under effective use was found to be 1.43 acres taking all farms together. The cultivated land of the absentee land owner is zero acre because they did not cultivate their own land. Average land holding under legal status was estimated at 2.11 acres comprising all categories together. Analysis of land use pattern shows that part tenants and the tenant farmers were in efforts to increase effective land use while the part operators and those of the part operator-cum-part tenants were found to decrease effective land use during the same period. This may attribute to either lacks in other non-land resources or their efforts to find out other income avenues outside agriculture.

Table 8. Size of land holding according to tenure category (in acre)

\begin{tabular}{l|c|c|c|c|c|c|c|c|c}
\hline $\begin{array}{l}\text { Tenure } \\
\text { category }\end{array}$ & $\begin{array}{c}\text { Cultivated } \\
\text { own land }\end{array}$ & Rented in & Rented out & $\begin{array}{c}\text { Mortgaged } \\
\text { in }\end{array}$ & $\begin{array}{c}\text { Mortgaged } \\
\text { out }\end{array}$ & $\begin{array}{c}\text { Total } \\
\text { cultivated } \\
\text { land }\end{array}$ & $\begin{array}{c}\text { Homestead } \\
\text { Others } \\
\text { (ponds, } \\
\text { fallow, } \\
\text { orchard) }\end{array}$ & $\begin{array}{c}\text { Total land } \\
\text { holding } \\
\text { under legal } \\
\text { status }\end{array}$ \\
\hline $\begin{array}{l}\text { Owner } \\
\text { operator }\end{array}$ & 1.94 & - & & - & - & 1.94 & 0.18 & 0.23 \\
$\begin{array}{l}\text { Part } \\
\text { operator }\end{array}$ & 3.20 & - & 0.58 & - & 0.41 & 2.21 & 0.18 & 0.24 \\
$\begin{array}{l}\text { Part } \\
\text { tenant }\end{array}$ & 0.78 & 0.11 & - & 0.19 & - & 1.08 & 0.09 & 0.12 \\
$\begin{array}{l}\text { Part } \\
\text { operator- } \\
\text { cum-part }\end{array}$ & 1.16 & 0.08 & 0.33 & 0.21 & - & 1.12 & 0.14 & 0.21 \\
tenant \\
$\begin{array}{l}\text { Tenant } \\
\text { Absentee }\end{array}$
\end{tabular}


Assets position of the farmers according to tenure category

It is apparent from the Table 9 that average assets value of absentee land owner and part operator were expectedly maximum being respectively Tk.203755 and Tk.172487 respectively during the study year. Value of dwelling houses constituted as well as sampled households taken together followed by other assets (26 percent) live animals (12 percent), farm implements ( 7 percent) and household durables (7 percent). Percentage of other assets may seem to be unexpectedly large to the readers but this attributes mostly to including trees which are at present valuable assets to rural people particularly to the land poor households

Table 9. Value of assets according to tenure category (amount in Tk.)

\begin{tabular}{|c|c|c|c|c|c|c|c|}
\hline $\begin{array}{l}\text { Tenur } \\
\text { category }\end{array}$ & $\begin{array}{l}\text { No. of } \\
\text { farmer }\end{array}$ & $\begin{array}{c}\text { Live } \\
\text { animals }\end{array}$ & $\begin{array}{c}\text { Farm } \\
\text { implements }\end{array}$ & $\begin{array}{c}\text { Dwelling } \\
\text { houses }\end{array}$ & $\begin{array}{l}\text { Household } \\
\text { durables }\end{array}$ & $\begin{array}{l}\text { Others } \\
\text { assets }\end{array}$ & Total \\
\hline $\begin{array}{l}\text { Owner } \\
\text { operator }\end{array}$ & 24 & $\begin{array}{c}17875 \\
(12)\end{array}$ & $\begin{array}{c}12275 \\
(8)\end{array}$ & $\begin{array}{c}70467 \\
(45)\end{array}$ & $\begin{array}{c}11270 \\
(7)\end{array}$ & $\begin{array}{c}43708 \\
(28)\end{array}$ & $\begin{array}{c}155595 \\
(100)\end{array}$ \\
\hline $\begin{array}{l}\text { Part } \\
\text { operator }\end{array}$ & 15 & $\begin{array}{c}18433 \\
(11)\end{array}$ & $\begin{array}{c}20247 \\
(12)\end{array}$ & $\begin{array}{c}85600 \\
(49)\end{array}$ & $\begin{array}{c}12407 \\
(7)\end{array}$ & $\begin{array}{l}35800 \\
(21)\end{array}$ & $\begin{array}{c}172487 \\
(100)\end{array}$ \\
\hline Part tenant & 11 & $\begin{array}{c}15664 \\
(25)\end{array}$ & $\begin{array}{l}1542 \\
(2)\end{array}$ & $\begin{array}{c}30818 \\
(48)\end{array}$ & $\begin{array}{c}2984 \\
(5)\end{array}$ & $\begin{array}{c}13000 \\
(20)\end{array}$ & $\begin{array}{c}64008 \\
(100)\end{array}$ \\
\hline $\begin{array}{l}\text { Part } \\
\text { operator- } \\
\text { cum-part } \\
\text { tenant }\end{array}$ & 5 & $\begin{array}{c}20170 \\
(18)\end{array}$ & $\begin{array}{l}1778 \\
(2)\end{array}$ & $\begin{array}{c}40400 \\
(37)\end{array}$ & $\begin{array}{l}7475 \\
(7)\end{array}$ & $\begin{array}{c}39000 \\
(39)\end{array}$ & $\begin{array}{c}108823 \\
(100)\end{array}$ \\
\hline Tenant & 7 & $\begin{array}{c}6529 \\
(15)\end{array}$ & $\begin{array}{c}1117 \\
(3)\end{array}$ & $\begin{array}{c}23142 \\
(55)\end{array}$ & $\begin{array}{c}2564 \\
(6)\end{array}$ & $\begin{array}{l}8667 \\
(21)\end{array}$ & $\begin{array}{l}42019 \\
(100)\end{array}$ \\
\hline $\begin{array}{l}\text { Absentee } \\
\text { land owner }\end{array}$ & 8 & $\begin{array}{l}11488 \\
(6)\end{array}$ & $\begin{array}{c}4467 \\
(2)\end{array}$ & $\begin{array}{c}111975 \\
(55)\end{array}$ & $\begin{array}{c}18075 \\
(9)\end{array}$ & $\begin{array}{l}57750 \\
(28)\end{array}$ & $\begin{array}{c}203755 \\
(100)\end{array}$ \\
\hline $\begin{array}{l}\text { All } \\
\text { categories }\end{array}$ & 70 & $\begin{array}{c}15947 \\
(12)\end{array}$ & $\begin{array}{l}9539 \\
(7)\end{array}$ & $\begin{array}{c}65343 \\
(48)\end{array}$ & $\begin{array}{l}9848 \\
(7)\end{array}$ & $\begin{array}{c}34952 \\
(26)\end{array}$ & $\begin{array}{c}135629 \\
(100)\end{array}$ \\
\hline
\end{tabular}

Source: Field Survey, 2008; Figure in parentheses indicate percentages of total

\section{Annual income according to tenure category}

Table 10 shows the average amount of annual income of a family. It is evident from the table that average income of an absentee land owner expectedly came from non farm source (74 percent) while other tenurial classes had higher income quite remarkably from farm sector. Average income of a tenant farmers also shared by non-farm sector by 59 percent because of the selling physical labor outside agriculture. Average income of an absentee land owner was found to be $1.17,0.89$, 2.18, 1.49 and 3.17 times higher than those of owner operator, part operator, part operator-gum-part tenant and tenant operator respectively during the same period in the study villages.

Table 10. Annual income per farm according to tenant category

\begin{tabular}{l|ccc|c|c|c}
\hline \multirow{2}{*}{$\begin{array}{l}\text { Tenure } \\
\text { category }\end{array}$} & \multicolumn{2}{|c|}{ Farm incom } & \multicolumn{2}{c|}{ Non-farm incom } & \multicolumn{2}{c}{ Total income } \\
\cline { 2 - 7 } & Amount (Tk) & Percent & Amount (Tk) & Percent & Amount (Tk) & Percent \\
\hline $\begin{array}{l}\text { Owner } \\
\text { operator }\end{array}$ & 85638 & 88 & 11458 & 12 & 97096 & 100 \\
Part operator & 100567 & 78 & 27700 & 22 & 128267 & 100 \\
Part tenant & 44373 & 85 & 7782 & 15 & 52155 & 100 \\
Part operator- & 67940 & 89 & 8400 & 11 & 76340 & 100 \\
cum-part & & & & & & \\
tenant & 14657 & 41 & 21214 & 59 & 35871 & 100 \\
Tenant & 29813 & 26 & 83750 & 74 & 113563 & 100 \\
Absentee land & & & & & & \\
owner & 67610 & 74 & 23380 & 26 & 90990 & 100 \\
All categories & & & & & & 100 \\
\hline
\end{tabular}

Source: Field Survey, 2008 


\section{Annual expenditure according to tenure category}

The result obtained out of annual expenditure analysis is shown in Table 11. It is clear from the Table 11 that 61 percent of the total annual expenditure was incurred for various items of family expenditure in the study area taking all categories together. Average amount of expenditure incurred for farm production was found to maintain a consistent relationship with tenurial categories, i.e., owner operator incurred maximum (50 percent) followed by part tenant (46 percent), part operator-cum-part tenant (44 percent), part operator (42 percent), tenant (12 percent) and absentee land owner ( 7 percent). It is evident from the table that tenant and that of the absentee land owner expectedly incurred quite minimum for farm activities possible because of diverse reasons.

Table 11. Annual expenditure per farm according to tenant category

\begin{tabular}{|c|c|c|c|c|c|c|}
\hline \multirow{2}{*}{$\begin{array}{l}\text { Tenure } \\
\text { category }\end{array}$} & \multicolumn{2}{|c|}{ Farm expenditure } & \multicolumn{2}{|c|}{ Family expenditure } & \multicolumn{2}{|c|}{ Total expenditure } \\
\hline & Amount (Tk.) & Percent & Amount (Tk.) & Percent & Amount (Tk.) & Percent \\
\hline $\begin{array}{l}\text { Owner } \\
\text { operator }\end{array}$ & 43438 & 50 & 43033 & 50 & 86471 & 100 \\
\hline Part operator & 47260 & 42 & 65213 & 58 & 112473 & 100 \\
\hline Part tenant & 19086 & 46 & 22482 & 54 & 41568 & 100 \\
\hline $\begin{array}{l}\text { Part operator- } \\
\text { cum-part } \\
\text { tenant }\end{array}$ & 27240 & 44 & 34150 & 66 & 61390 & 100 \\
\hline Tenant & 3943 & 12 & 29386 & 88 & 33329 & 100 \\
\hline $\begin{array}{l}\text { Absentee land } \\
\text { owner }\end{array}$ & 6875 & 7 & 91475 & 93 & 98350 & 100 \\
\hline All categories & 31145 & 39 & 48093 & 61 & 79238 & 100 \\
\hline
\end{tabular}

Source: Field Survey, 2008

\section{Annual saving of the respondent farmers}

Table 12 shows the average amount of annual savings of the interviewees of different tenure categories. Average tenant farmer was found to have expectedly minimum savings while those of part operator and absentee land owner had maximum savings during the same period. The overall average amount of annual savings has been estimated at Tk. 11752 during the study year. It is apparent from the table that the farm families irrespective of tenure categories had positive savings at the end of the year which is definitely an encouraging phenomenon.

Table 12. Annual saving of the families according to tenurial category

\begin{tabular}{|c|c|c|c|}
\hline Tenure category & Income & Expenditure & Savings \\
\hline Owner operator & 97096 & 86471 & 10625 \\
\hline Part operator & 128267 & 112473 & 15794 \\
\hline Part tenant & 52155 & 41568 & 10587 \\
\hline Part operator-cum-part tenant & 76340 & 61390 & 14950 \\
\hline Tenant & 35871 & 33329 & 2542 \\
\hline Absentee land owner & 113563 & 98350 & 15213 \\
\hline All categories & 90990 & 79238 & 11752 \\
\hline
\end{tabular}

Source: Field Survey, 2008

\section{Conclusions}

Bangladesh is an agricultural country. Majority of its people live in rural areas and are dependent directly on agricultural pursuit. Its share to the national GDP is 21.11 percent and vary much important to the national economy. Performance of the sector is still not up to the expected level. A majority of people engage in agricultural profession whose income level is very low, so the overall economic development of the country depends mainly on increased agricultural production. Bangladesh has vast fertile land resources. Increasing productivity therefore, is not a very difficult task. A significant stepping stone for accelerating the pace of economic development is the modernization of agriculture. For this required adequate knowledge and money. But we find this study that farmers were not enough educated and most of them are poor. For improving their socio-economic condition this development was essential. We found from this study that the education status of famers was better compared to the past. For developed their socioeconomic condition more land tenure system must be modernized by using modern equipment, HYV seedfertilizer-water technology. 


\section{References}

Bishop, C.E. and W.D. Toussaint, (1958): Introduction to Agricultural Economic Analysis, New York, John willey and Sons, Inc., New York.

Hasan, M.A. (1983): A Study of Farm structure and Resource Use with Emphasis on Agricultural Credit in a Selected Garo Hill Area of Jamalpur District. Unpublished Masterôs thesis submitted to the Department of Agricultural Finance, Bangladesh Agricultural University, Mymensingh.

Jabbar, M.A.(1977): Relative Productive Efficiency of Different Tenure Classes in Selected Areas of Bangladesh. The Bangladesh Development Studies. BIDS, Vol.1. January.

Mandal, M.A.S.(1979): Farm Size, Tenure and Productivity in an Area of Bangladesh. The Bangladesh Journal of Agricultural Economics, III, 2, Dec, 1980.
MoF (2007): Bangladesh Economic Review, Economic Division, Ministry of Finance, Government of the Peopleố Republic of Bangladesh, Dhaka, Bangladesh. Pakistan (1962): Government of Pakistan: Pakistan Census of Agriculture, 1960, Karachi, Ministry of Agriculture.

Sikder, M.A.I. (1985): An Investigation in the Effect of Land Tenure system on Availability and Utilization of Credit in Some Selected Areas of Rangpur and Mymensingh District. Unpublished Masterôs thesis submitted to the Department of Agricultural Finance, Bangladesh Agricultural University, Mymensingh.

Taslim, M.A. and F.U. Ahamed (1992): An Analysis of Land leasing in Bangladesh Agriculture. Economic Development and Cultural Change. 3: 615-628. 